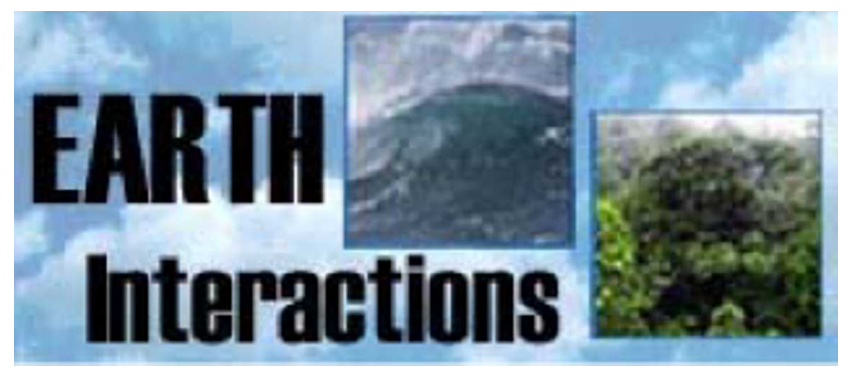

Copyright (c) 2006, Paper 10-018; 5,789 words, 6 Figures, 0 Animations, 4 Tables. http://EarthInteractions.org

\title{
Effects of Uncertainty in Climate Inputs on Simulated Evapotranspiration and Runoff in the Western Arctic
}

\section{A. Rawlins*}

Water Systems Analysis Group, Institute for the Study of Earth, Oceans, and Space, University of New Hampshire, Durham, New Hampshire

\section{S. Frolking}

Water Systems Analysis Group, Institute for the Study of Earth, Oceans, and Space, and Department of Earth Sciences, University of New Hampshire, Durham, New Hampshire

\section{R. B. Lammers}

Water Systems Analysis Group, Institute for the Study of Earth, Oceans, and Space, University of New Hampshire, Durham, New Hampshire

\section{J. Vörösmarty}

Water Systems Analysis Group, Institute for the Study of Earth, Oceans, and Space, and Department of Earth Sciences, University of New Hampshire, Durham, New Hampshire

Received 8 November 2005; accepted 19 July 2006

* Corresponding author address: M. A. Rawlins, Complex Systems Research Center, University of New Hampshire, 39 College Rd., Durham, NH 03824.

E-mail address: michael.rawlins@unh.edu 
Earth Interactions - Volume 10 (2006) - Paper No. 18 • Page 2

\begin{abstract}
Hydrological models require accurate precipitation and air temperature inputs in order to adequately depict water fluxes and storages across Arctic regions. Biases such as gauge undercatch, as well as uncertainties in numerical weather prediction reanalysis data that propagate through water budget models, limit the ability to accurately model the terrestrial arctic water cycle. A hydrological model forced with three climate datasets and three methods of estimating potential evapotranspiration (PET) was used to better understand the impact of these processes on simulated water fluxes across the Western Arctic Linkage Experiment (WALE) domain. Climate data were drawn from the NCEP-NCAR reanalysis (NNR) (NCEP1), a modified version of the NNR (NCEP2), and the Willmott-Matsuura (WM) dataset. PET methods applied in the model were Hamon, Penman-Monteith, and Penman-Monteith using adjusted vapor pressure data.

High vapor pressures in the NNR lead to low simulated evapotranspiration (ET) in model runs using the Penman-Monteith PET method, resulting in increased runoff. Annual ET derived from simulations using Penman-Monteith PET was half the magnitude of ET simulated when the Hamon method was used. Adjustments made to the reanalysis vapor pressure data increased the simulated ET flux, reducing simulated runoff. Using the NCEP2 or WM climate data, along with the Penman-Monteith PET function, results in agreement to within $7 \%$ between the simulated and observed runoff across the Yukon River basin. The results reveal the high degree of uncertainty present in climate data and the range of water fluxes generated from common model drivers. This suggests the need for thorough evaluations of model requirements and potential biases in forcing data, as well as corroborations with observed data, in all efforts to simulate arctic water balances.
\end{abstract}

KEYWORDS: Runoff; Evapotranspiration; Arctic

\title{
1. Introduction
}

Changes are occurring to high-latitude environments with further alteration likely under several global change scenarios. Responses in the arctic environment may include alterations to the landscape and in water fluxes and stores. While conceptual water balance models have proved useful in assessing contemporary hydrological conditions and in modeling future states, general circulation models have not proved accurate enough to close water budgets in hydrological applications. Precipitation simulated in GCMs tends to be overestimated and seasonal dynamics are often inaccurate (Kite and Haberlandt 1999; Töyrä et al. 2005). Hydrological models that account for phase changes in soil water (Rawlins et al. 2003; Su et al. 2005) have recently been adopted in hopes of improving simulated water budgets across high-latitude regions.

Water budget models are dependent on accurate inputs of air temperature and especially precipitation in order to adequately depict the spatial and temporal dynamics of arctic water fluxes. Deficiencies leading to biases in model input data can significantly impact the usefulness of the data for climate change research and other efforts to solve environmental problems. In a sensitivity experiment, an arctic hydrological model was more sensitive to changes in daily precipitation than in the prescribed land surface parameterizations (Rawlins et al. 2003). Uncertainties in precipitation data used to drive hydrological models are a particular problem in the Arctic where gauge undercatch is often substantial. Precipitation underes- 
Earth Interactions • Volume 10 (2006) - Paper No. 18 • Page 3

timates of $20 \%$ to $25 \%$ have been determined across North America (Karl et al. 1993), while biases of $80 \%$ to $120 \%$ (in winter) have been estimated for the terrestrial Arctic north of $45^{\circ} \mathrm{N}$ (Yang et al. 2005). In regions where precipitation exceeded potential evapotranspiration (PET), uncertainty in precipitation translated to an uncertainty in simulated runoff of roughly similar magnitude (Fekete et al. 2004). To better understand the effect of data biases and uncertainties on simulated water budgets, we perform a series of model simulations using three climate drivers and three methods for estimating PET across the Western Arctic Linkage Experiment (WALE) domain. Goals of the WALE project include identification of uncertainties in regional hydrology and carbon estimates with respect to uncertainties in (i) driving datasets and (ii) among different models. The present paper focuses on how the limitations and uncertainties in three climate datasets affect our ability to accurately simulate water budgets across the terrestrial Arctic. Additional details of the WALE project can be found in the overview paper by McGuire et al. (McGuire et al. 2005, manuscript submitted to Earth Interactions).

\section{Methods}

\subsection{Overview}

A series of simulations using three climate drivers and three methods for estimating PET (nine model runs) was made for the period 1980-2001 with a hydrological model (section 2.2.). We use commonly available datasets (section 2.3.) to judge the impact of climate on the simulated water budgets. PET is estimated using the Hamon method [Hamon 1963; Equation (A1) in appendix A], the surfacedependent Penman-Monteith method [PM; Monteith 1965; Equation (A2) in appendix A], and the PM method with adjusted vapor pressure data, described in section 2.4. Details of the simulations to produce the nine scenarios and the comparisons with observed evapotranspiration (ET) and runoff are described in section 2.4.

\subsection{Model description}

We use the Pan-Arctic Water Balance Model (PWBM; Rawlins et al. 2003) to simulate runoff and ET at an implicit daily time step across the WALE domain. This hydrological model uses gridded fields of plant rooting depth, soil characteristics (texture, organic content), and vegetation and is driven with daily time series of precipitation and air temperature. The PWBM incorporates a soil organic layer and a soil moisture phase-change submodel that partitions water to solid and liquid amounts. Spatial fields of air temperature, vegetation, and soil characteristics provide the inputs to the thaw/freeze submodel. A detailed description of the model was provided in Rawlins et al. (Rawlins et al. 2003). Simulations in the present study were performed on the Northern Hemisphere Equal-Area Scalable Earth (EASE)-Grid at a resolution of $25 \mathrm{~km} \times 25 \mathrm{~km}$ across 3511 grid cells that define the domain. The WALE domain encompasses Alaska and the upper headwaters of the Yukon basin in northwestern Canada. Simulations are performed over the period 1980-2001.

\subsection{Input datasets}

Water budget simulations are made using three climate driver datasets. We use precipitation and air temperature from the National Centers for Environmental 
Earth Interactions - Volume 10 (2006) - Paper No. 18 • Page 4

Prediction-National Center for Atmospheric Research (NCEP-NCAR) reanalysis project (NNR; Kistler et al. 2001), hereinafter referred to as NCEP1. We also use precipitation data (NCEP2), which represents an improvement to the standard NNR fields through application of a statistical downscaling approach based on a probability transformation for precipitation (Serreze et al. 2003). The NCEP2 air temperature grids are derived from NNR data using a method that accounts for elevation effects. The third climate driver set is the Willmott-Matsuura (WM) archive (Willmott and Matsuura 2001). The WM archive was produced using the Global Historical Climatology Network (GHCN) version 2 data (Vose et al. 1992) and Legates and Willmott's (Legates and Willmott 1990a; Legates and Willmot 1990b) station records of monthly and annual air temperature and total precipitation. Willmott-Matsuura climate data are available through year 2000. Table 1 summarizes the climate datasets used in the PWBM simulations. Mean annual precipitation across the WALE domain is highest for NCEP1 $\left(650 \mathrm{~mm} \mathrm{yr}^{-1}\right)$ and lowest for the WM archive (510 $\mathrm{mm} \mathrm{yr}^{-1}$; Figure 1; Table 2). A significant problem with the NCEP reanalysis model is a severe oversimulation of summer precipitation over land areas due to excessive convective precipitation (Serreze and Hurst 2000). The statistical method used to create the NCEP2 precipitation reduces this bias, and the NCEP2 precipitation average $\left(580 \mathrm{~mm} \mathrm{yr}^{-1}\right)$ falls between the excessive NCEP1 data and the unadjusted WM data (Figure 1).

Land cover is defined from a new 1-km resolution vegetation classification for Alaska that prescribes fractional cover for six vegetation types in each $25 \mathrm{~km} \times 25$ km EASE-Grid cell. Two Advanced Very High Resolution Radiometer (AVHRR)based land cover classifications for Alaska (Fleming 1997) and Canada (Cihlar and Beaubien 1998) were merged and aggregated into five major vegetation types using an expert model (Calef et al. 2005). The cover types are black spruce, white spruce, deciduous forest, tundra, coastal forest, and bare ground (encompasses areas of rock and ice). With 1991 as the base year, transient land cover was interpolated backward and forward for 1950 to 2000 using a hierarchical logistic regression approach, the historic fire record, and ecological knowledge on succession. Tundra vegetation makes up the majority (55\%) of the WALE domain, with coniferous forest (black spruce, white spruce, and coastal forest) second-most prevalent. The same parameter specifications are used for these coniferous forest grids in the PWBM runs. Across the Yukon basin, tundra again is dominant, with slightly more coniferous forest $(39 \%)$ than the entire WALE domain contains (22\%). For a given climate driver and PET method configuration, the PWBM was run separately for each land cover type over the 1980-2001 period. A 50-yr spinup

Table 1. Climate dataset used in PWBM simulations and original source for precipitation, air temperature, and vapor pressure data used in the model runs. NNR is the NCEP-NCAR reanalysis. NNRa indicates NNR data adjusted by methods in Serreze et al. (Serreze et al. 2003); NNRb is NNR adjusted for effects of elevation on air temperature interpolations; and NNRc denotes NNR vapor pressures that are reduced by the difference with CRU vapor pressure data.

\begin{tabular}{lccl}
\hline Dataset & Precipitation & Air temperature & Vapor pressure \\
\hline NCEP1 & NNR & NNR & NNR/NNRc \\
NCEP2 & NNRa & NNRb & NNRc \\
WM & WM & WM & NNRc \\
\hline
\end{tabular}



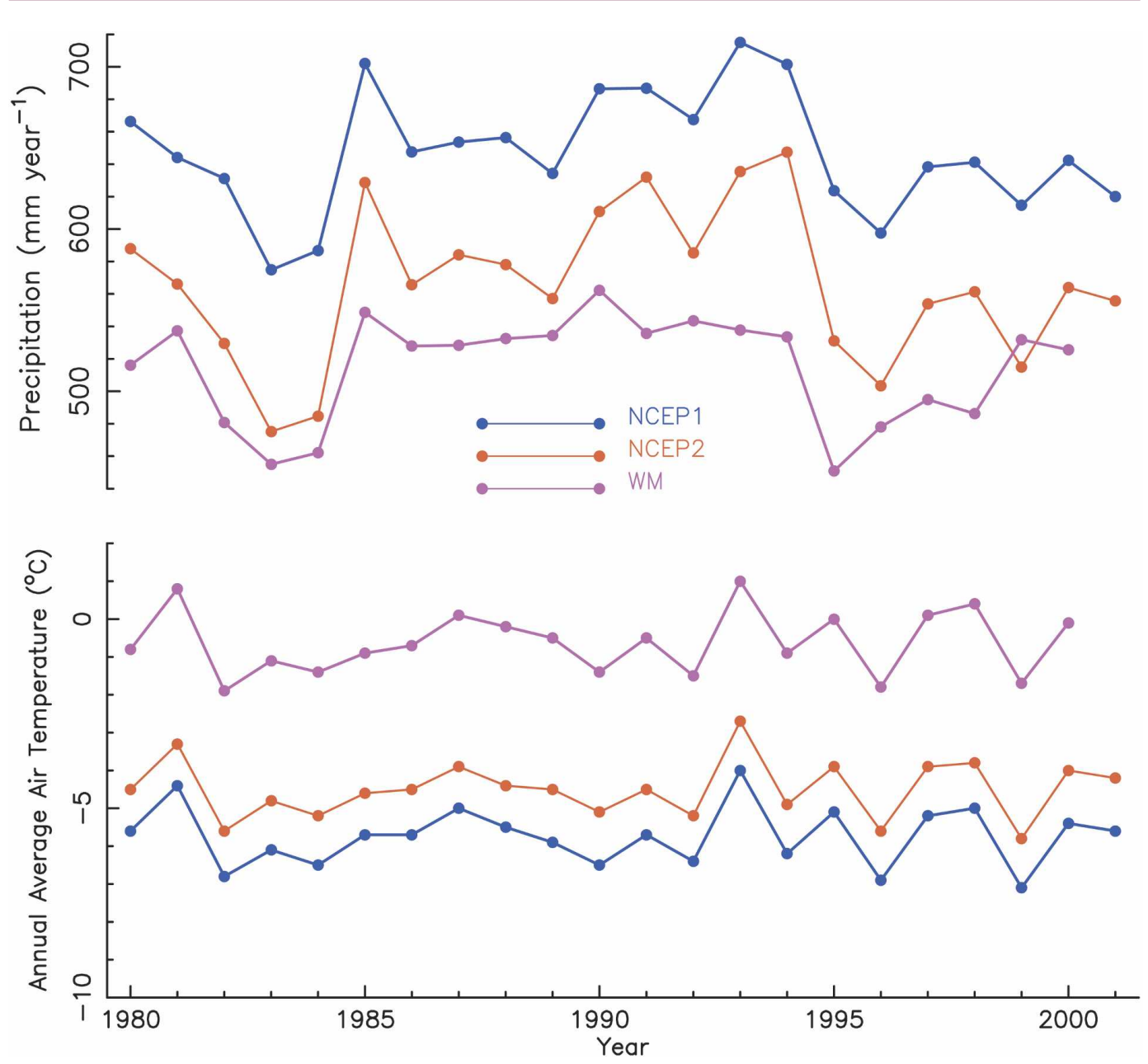

Figure 1. (top) Annual total precipitation and (bottom) mean annual air temperature across the WALE domain for the years 1980-2001. Precipitation and air temperatures are drawn from NCEP1 (Kistler et al. 2001), a version based on a statistical downscaling (Serreze et al. 2003) of NCEP2, and the WM archive (Willmott and Matsuura 2001).

was first performed to stabilize model soil moisture. Runoff and ET for each grid cell is a weighted average of runoff or ET across each land cover type in the grid. We use this "mosaic" of ET or runoff in the analysis to follow. Simulated ET is the total water loss from the surface, which includes transpiration from plants, evaporation from soils, and sublimation from snow.

\subsection{Model application and analysis}

Simulated water fluxes of runoff and ET were evaluated and compared with observed data where available. We use discharge data from the downstream site (Pilot Station) on the Yukon River for comparison with the simulated runoff across the Yukon basin. Observed ET data are drawn from two sites across Alaska 
Earth Interactions - Volume 10 (2006) - Paper No. 18 • Page 6

Table 2. Long-term mean simulated ET, runoff, and climate across the WALE domain from the three climate drivers and three PET methods. Here, $P$ is mean annual

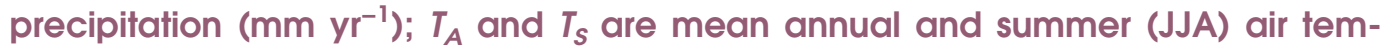
perature, respectively. PET methods (described in section 2.4.) are the Hamon method (Hamon 1963; Equation (A1)), the PM method (Monteith 1965; Equation (A2)), and the PM method with adjusted vapor pressure data (PM*). Averages for ET are taken from the time series in Figure 3, and runoff averages are derived from the time series in Figure 4.

\begin{tabular}{|c|c|c|c|c|c|c|c|c|c|}
\hline \multirow[b]{2}{*}{ Dataset } & \multicolumn{3}{|c|}{ Climate $\left(\mathrm{mm} \mathrm{yr}^{-1},{ }^{\circ} \mathrm{C}\right)$} & \multicolumn{3}{|c|}{ ET $\left(\mathrm{mm} \mathrm{yr}^{-1}\right)$} & \multicolumn{3}{|c|}{ Runoff $\left(\mathrm{mm} \mathrm{yr}^{-1}\right)$} \\
\hline & $\mathrm{P}$ & $\mathrm{T}_{\mathrm{A}}$ & $\mathrm{T}_{\mathrm{S}}$ & Hamon & PM & $\mathrm{PM}^{*}$ & Hamon & PM & $\mathrm{PM}^{*}$ \\
\hline NCEP1 & 650 & -6.9 & 9.2 & 267 & 115 & 146 & 366 & 504 & 474 \\
\hline NCEP2 & 580 & -5.8 & 9.7 & 263 & 116 & 143 & 296 & 443 & 418 \\
\hline WM & 510 & -3.8 & 12.5 & 275 & 112 & 139 & 243 & 403 & 373 \\
\hline
\end{tabular}

(Table 3). We compare PWBM simulated summer total [June-August (JJA)] ET at the grid cell in which the observed site is located with the observed value, which was measured using flux towers eddy covariance measurements (Beringer et al. 2005; Liu et al. 2005).

Within the PWBM simulated PET was estimated using the relatively simple Hamon function [Hamon 1963; Equation (A1) in appendix A], a physically based, surface-dependent combination approach [PM; Monteith 1965; Equation (A2) in appendix A], and the PM method forced with adjusted vapor pressure data. These adjustments were made after problems were identified with the NNR humidity data. The Hamon method falls into a class known as reference-surface PET methods, that is, methods that produce evaporation that would result from a specific land surface known as a reference crop. In contrast, the PM approach is known as a surface-dependent PET method; that is, it produces the evaporation that would occur from any of a variety of designated land surfaces. In the PM method, parameterizations for quantities such as leaf conductance and aerodynamic resistance (see appendix B) are a function of the land cover type as described by Federer et al. (Federer et al. 1996). Aerodynamic resistances are taken from the neutral wind profile equation. Net radiation time series from the NNR dataset are used in the PM approach. We chose the Penman-Monteith method since it was

Table 3. Observed JJA ET at two sites in Alaska and simulated JJA ET for $25 \mathrm{~km} \times 25$ $\mathrm{km}$ EASE-Grid in which site is located. Simulated ET is taken from model runs using the Hamon method, the PM method, and the adjusted PM method (PM*). For each PET method we averaged simulated ET over the three climate driver (NCEP1, NCEP2, and WM) runs. Eddy covariance measurements of latent heat were reported for Council $\left(64.8^{\circ} \mathrm{N}, 163.7^{\circ} \mathrm{W}\right.$; Beringer et al. 2005) and Delta Junction $\left(63.9^{\circ} \mathrm{N}, 145.7^{\circ} \mathrm{W}\right.$; Liu et al. 2005). Observations were taken from JJA 1999 at Council and from JJA 2002 at Delta Junction.

\begin{tabular}{lrcccr}
\hline & \multicolumn{4}{c}{ ET $\left(\mathrm{mm} \mathrm{season}^{-1}\right)$} \\
\cline { 2 - 6 } \multicolumn{1}{c}{ Location } & Obs & Hamon & PM & PM* & Period \\
\hline Council & 97 & 93 & 81 & 81 & 18 Jun 1999-22 Aug 1999 \\
Delta Junction & 178 & 142 & 55 & 61 & 1 Jun 2002-31 Aug 2002 \\
\hline
\end{tabular}




\section{Earth Interactions - Volume 10 (2006) - Paper No. 18 - Page 7}

found to be the least biased of 11 methods applied over the conterminous United States (Vörösmarty et al. 1998). Our analysis focuses on simulated runoff and ET obtained from a model run using a specific combination of the climate driver and PET method. Although we mention the PET method when discussing model implementation, analysis of model output is restricted to simulated ET, which is distinguished from PET through limitations imposed by soil water deficit within the model run. Vapor pressure data required for the PM function are not available from the NCEP2 and WM datasets, and we use those from the NNR project in all simulations involving the PM PET method.

Surface-dependent PET functions such as PM use air temperature, vapor pressure data, and other climate drivers to estimate the potential flux of water from vegetated surfaces. Observed meteorological station data for several sites in Alaska were compared with relative humidities derived from NNR vapor pressure and air temperatures. Mean daily air temperature and dewpoint at the sites for the year 2000 were taken from stations in the Global Summary of the Day (SOD) database distributed by the National Climatic Data Center. Relative humidities derived from NNR data are near $100 \%$ during summer, while lower values and greater variability are present in the station data (Figure 2). High humidities are consistent with excessive surface evaporation rates in the NNR, a problem that
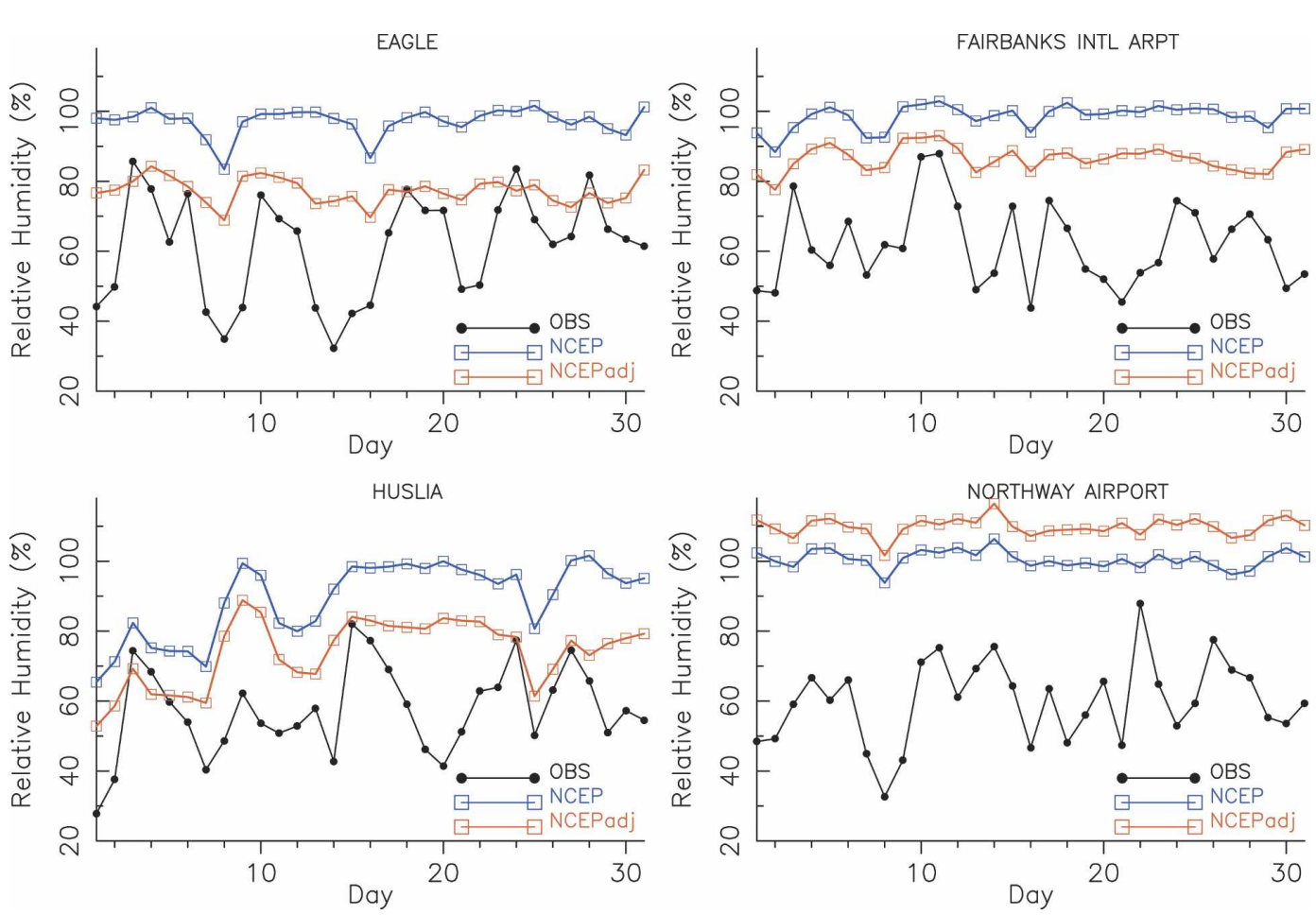

Figure 2. Daily average relative humidity for July 2000 derived from NCEP-NCAR reanalysis, vapor pressure (VP) data (NCEP), reanalysis VP adjusted using CRU monthly VP (NCEPadj), and air temperature and dewpoint in the SOD dataset (OBS). Excess humidity depicted in the reanalysis data limits ET when used in the PWBM model simulations. 
Earth Interactions • Volume 10 (2006) - Paper No. 18 • Page 8

may be related to excessive soil moisture and solar radiation during summer in the reanalysis data (Serreze and Hurst 2000).

To better understand the effect of NNR moisture biases, gridded vapor pressures from the University of East Anglia's Climate Research Unit (CRU; http://www. cru.uea.ac.uk) are used to adjust the NNR vapor pressure data at each EASE-grid cell. The CRU data are monthly averages, and the adjustment to the gridded NNR daily vapor pressure data is

$$
\mathrm{VP}_{D}=\mathrm{VP}_{\mathrm{NNR}}-\left(\mathrm{VP}_{M}-\mathrm{VP}_{\mathrm{CRU}}\right)
$$

where $\mathrm{VP}_{D}$ are the adjusted daily NNR vapor pressures $(\mathrm{kPa})$ at the EASE-grid, $\mathrm{VP}_{\mathrm{NNR}}$ is the daily NNR vapor pressure, $\mathrm{VP}_{M}$ is monthly average vapor pressure from NNR, and $\mathrm{VP}_{\mathrm{CRU}}$ is monthly $\mathrm{CRU}$ vapor pressure. CRU vapor pressures are generally lower than NNR values across most of interior Alaska, while similar vapor pressures occur across coastal regions. These adjusted $\mathrm{VP}_{D}$ values are used in a third suite of PWBM simulations involving each climate driver set. We refer to the PET method for these simulations as the "adjusted PM method" (PM* in Tables 2, 3, and 4). When the adjusted NNR vapor pressures $\left(\mathrm{VP}_{D}\right)$ are used, simulated ET increases an average of $30 \mathrm{~mm} \mathrm{yr}^{-1}$ over the default PM configuration (Table 2).

\section{Results}

\subsection{Simulated evapotranspiration}

Comparisons between simulated and observed ET rates illustrate the effect of biases in the vapor pressure data. Table 3 shows observed ET along with the average simulated ET for the Hamon, PM, and adjusted PM PET methods, where the average for each PET method is calculated across the three climate driver simulations. At the coastal tundra site (Council), small differences (no greater than 16 millimeters per summer) in ET are noted. Indeed, differences between NNR and CRU vapor pressures across coastal regions are small; therefore, simulated ET using the default and the adjusted vapor pressures, for the Council grid cell, are identical (81 millimeters per season). At the interior site (Delta Junction) greater differences are evident. Simulations using the PM method lead to ET rates much

Table 4. MAD ( $\mathrm{mm} \mathrm{yr}^{-1}$ ) in simulated annual runoff as compared to observed runoff across the Yukon basin. MAD $=(1 / 22) \sum_{i=1}^{22}\left|R_{s}-R_{o}\right|$, where $R_{s}$ is the simulated annual runoff and $R_{O}$ is the observed. Using signed differences, overestimation $\left(\sum_{i=1}^{22} R_{s}-R_{o}>0\right)$ is indicated with $\uparrow$, and underestimation $\left(\sum_{i=1}^{22} R_{s}-R_{o}<0\right)$ is shown with $\downarrow$.

\begin{tabular}{lcccc}
\hline & \multicolumn{4}{c}{$\mathrm{MAD}\left(\mathrm{mm} \mathrm{yr}^{-1}\right)$} \\
\cline { 2 - 5 } Dataset & Hamon & PM & PM $^{*}$ & Average \\
\hline NCEP1 & $110 \uparrow$ & $260 \uparrow$ & $230 \uparrow$ & 200 \\
NCEP2 & $130 \downarrow$ & $30 \uparrow$ & $30 \downarrow$ & 60 \\
WM & $170 \downarrow$ & $20 \uparrow$ & $30 \downarrow$ & 70 \\
Average & 137 & 103 & 93 & - \\
\hline
\end{tabular}




\section{Earth Interactions - Volume 10 (2006) • Paper No. 18 - Page 9}

lower than observed values. When the adjusted vapor pressures are used, ET increases 6 millimeters per summer for the Delta Junction grid cell.

Across the WALE domain, low NNR-derived vapor pressure deficits cause reduced PET and ET rates. For the three climate driver simulations, the ET average (1980-2001) when using PM is $113 \mathrm{~mm} \mathrm{yr}^{-1}$, whereas the simulations using Hamon are over $100 \%$ higher, averaging $268 \mathrm{~mm} \mathrm{yr}^{-1}$ (Figure 3a). The ET rates, when the PM method is used, are less than half of the Hamon ET values. Differences in annual ET when PM is used are also relatively small, averaging 115, 116, and $112 \mathrm{~mm} \mathrm{yr}^{-1}$ for NCEP1, NCEP2, and WM climate (Table 2). Long-term mean monthly ET is $15-20 \mathrm{~mm}^{\text {month }}{ }^{-1}$ lower for the PM method versus Hamon (Figure 3b). For NCEP2 climate, simulated ET from the adjusted PM method is

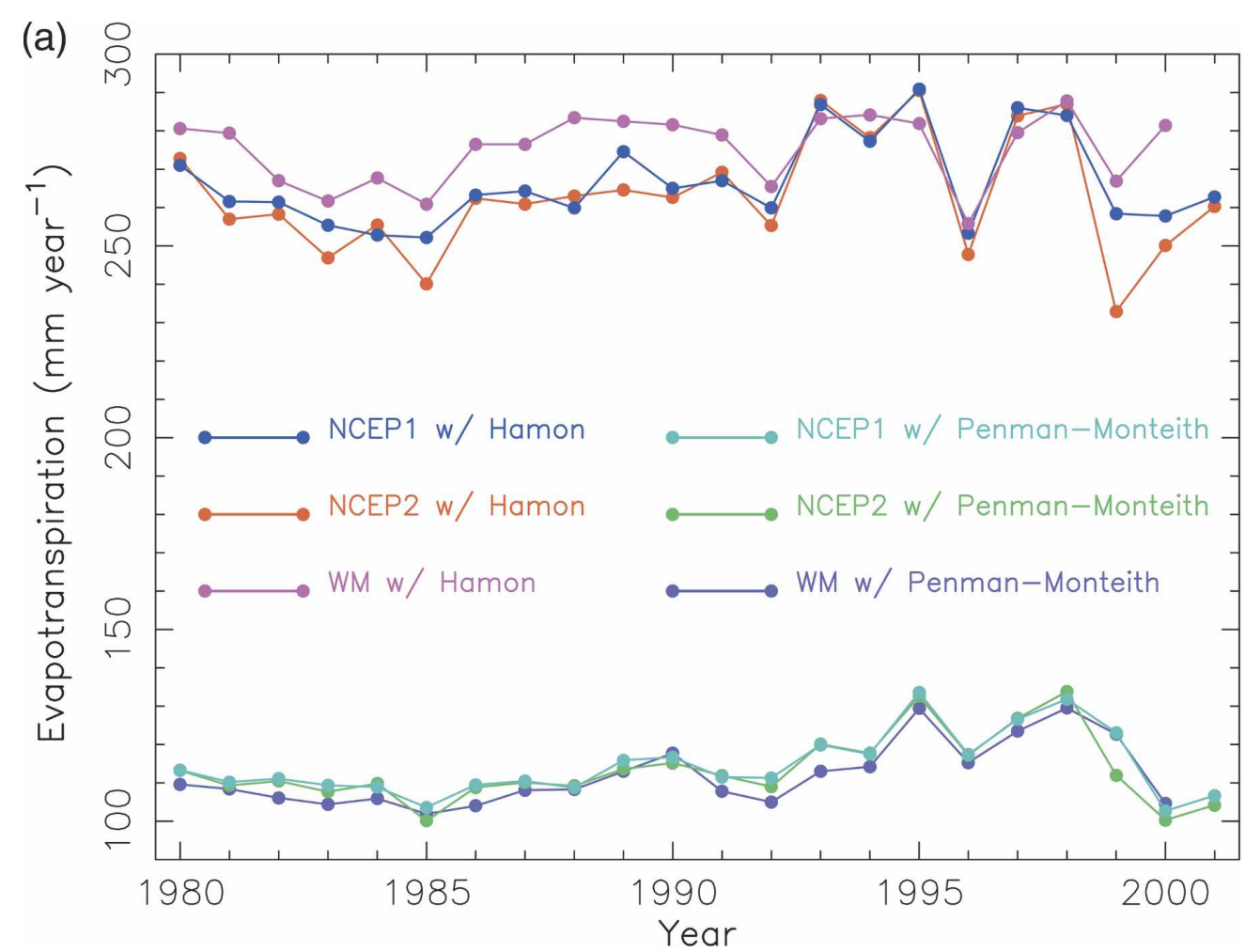

Figure 3. PWBM-simulated annual ET across the WALE domain for the period 19802001. In Figures 2-5, NCEP1 indicates climate data from NNR (Kistler et al. 2001), NCEP2 is the modified NNR dataset from Serreze et al. (Serreze et al. 2003), and WM is simulations using Willmott and Matsuura (Willmott and Matsuura 2001) data. Annual ET, computed in a given PWBM simulation, is the sum of sublimation from snowpack and transpiration from vegetated surfaces. Figure legends indicate which climate data and PET method were used in the given model run (e.g., NCEP1 with Hamon). (a) Annual totals of ET from the three climate drivers and Hamon and PM PET for 1980-2001. (b) Monthly climatology from the standard simulation runs. (c) Annual ET from simulations with NCEP2 climate and Hamon, PM, and adjusted PM PET methods. 
Earth Interactions - Volume 10 (2006) - Paper No. 18 - Page 10
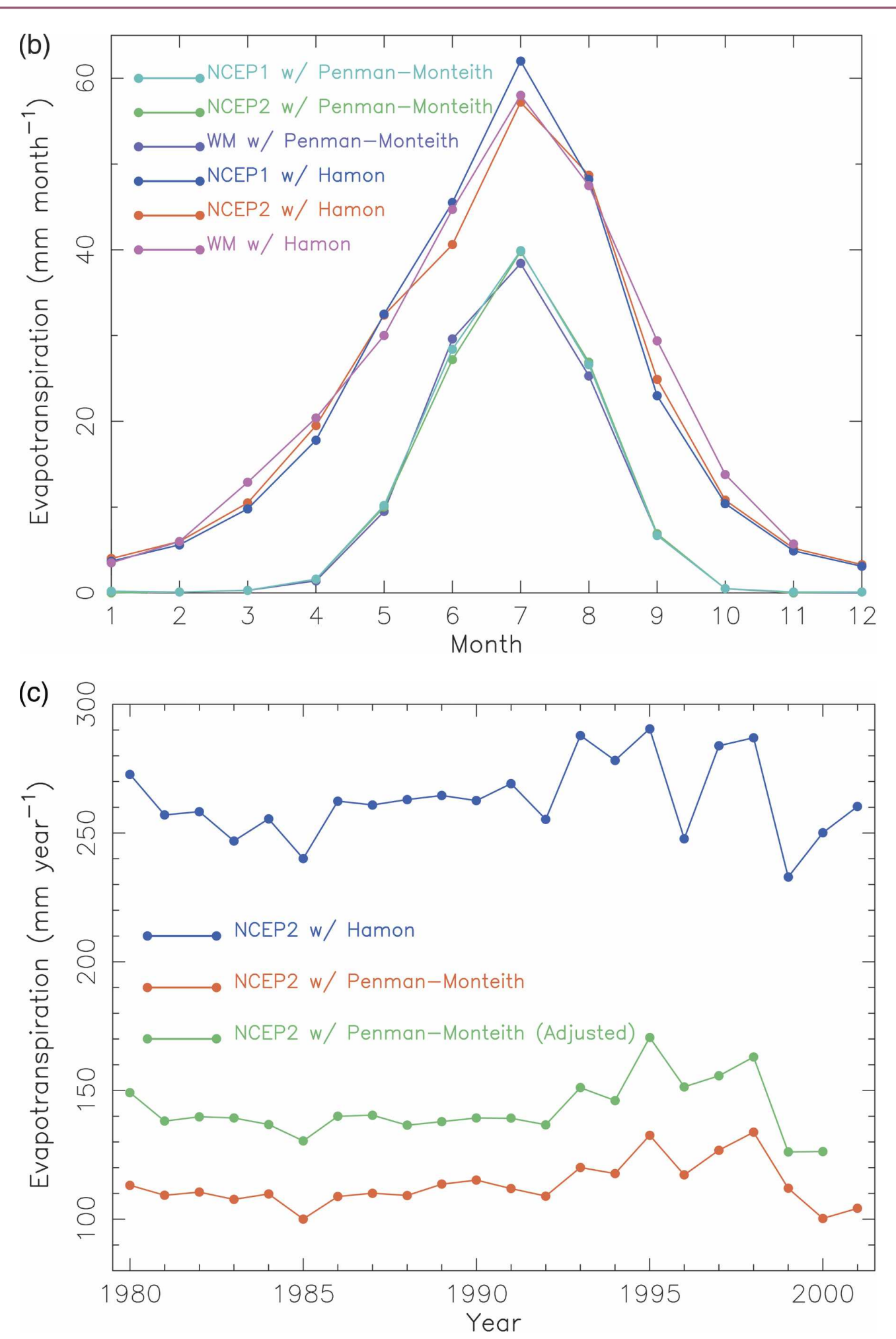

Figure 3. (Continued) 
Earth Interactions - Volume 10 (2006) - Paper No. 18 • Page 11

$23 \%$ higher than the ET rates from the model run using the default PM PET method (Figure 3c; Table 2), while the Hamon method again is approximately $100 \%$ higher. These comparisons illustrate well the underestimation of ET in simulations using the default PM method and NNR vapor pressures.

\subsection{Simulated runoff}

Differences between the climate data inputs as well as the NNR humidity anomaly are evident in PWBM runoff simulations. Annual runoff is highest when NCEP1 data are used and lowest with WM. Long-term mean simulated runoff across the WALE domain averages 366, 296, and $243 \mathrm{~mm} \mathrm{yr}^{-1}$ from the NCEP1, NCEP2, and WM simulations, respectively (Table 2). Correlation between NCEP1 and NCEP2 runoff is 0.92 , which is expected, whereas the correlation between NCEP2 and WM is 0.55 (Figure 4a). When the PM method is used, runoff averages 504, 443, and $403 \mathrm{~mm} \mathrm{yr}^{-1}$, respectively. Correlations here are 0.92 (NCEP1/NCEP2) and 0.21 (NCEP2/WM) (Figure 4b). Although less well correlated in time, the NCEP2 and WM climate data produce runoff of similar magnitude. Differences between runoff from simulations using NCEP2 or WM climate

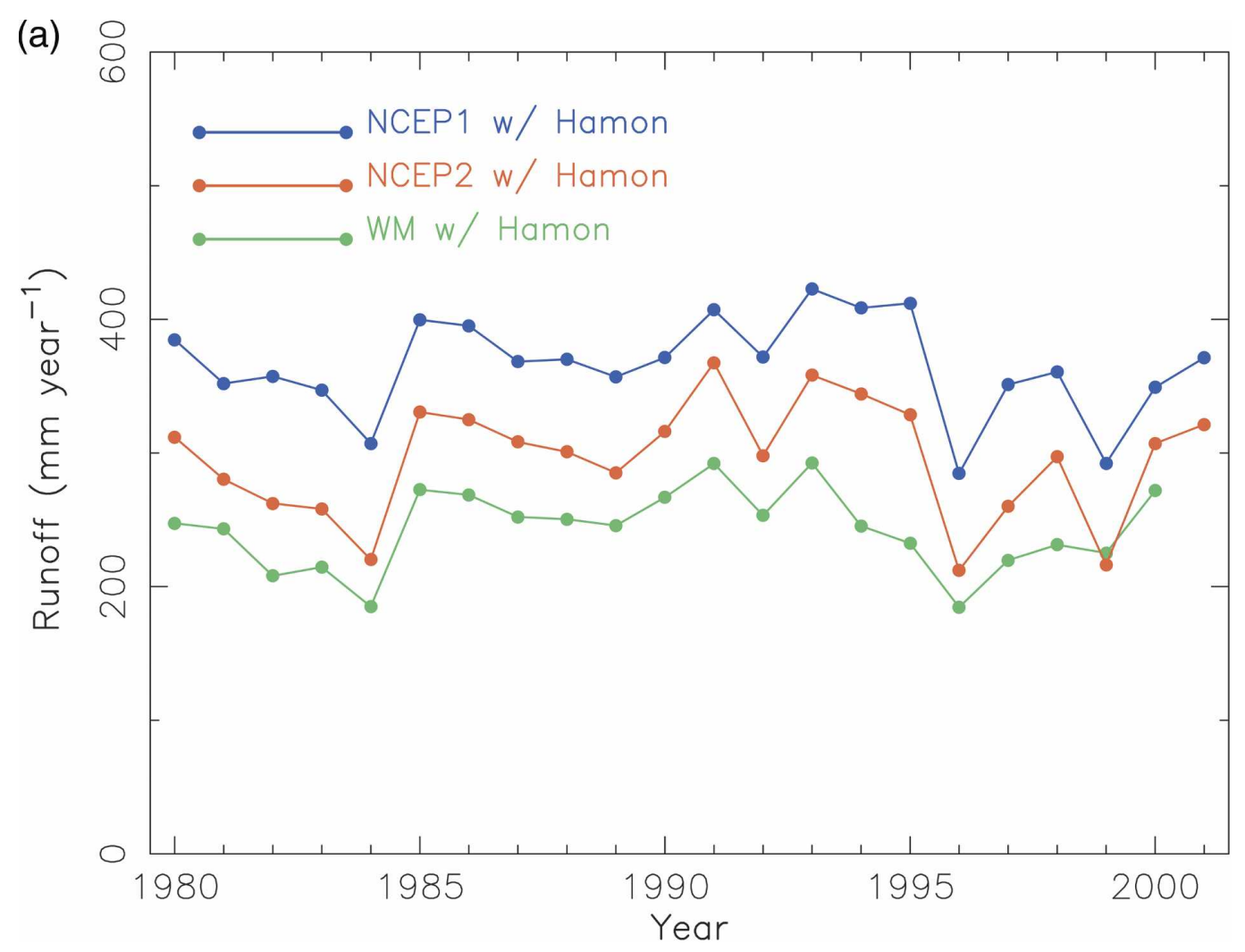

Figure 4. Simulated annual runoff across the WALE domain for 1980-2001. (a) Three climate driver simulations using the Hamon method for PET. (b) Simulations using the PM method. (c) NCEP2 climate together with each PET method. 
Earth Interactions - Volume 10 (2006) - Paper No. 18 - Page 12
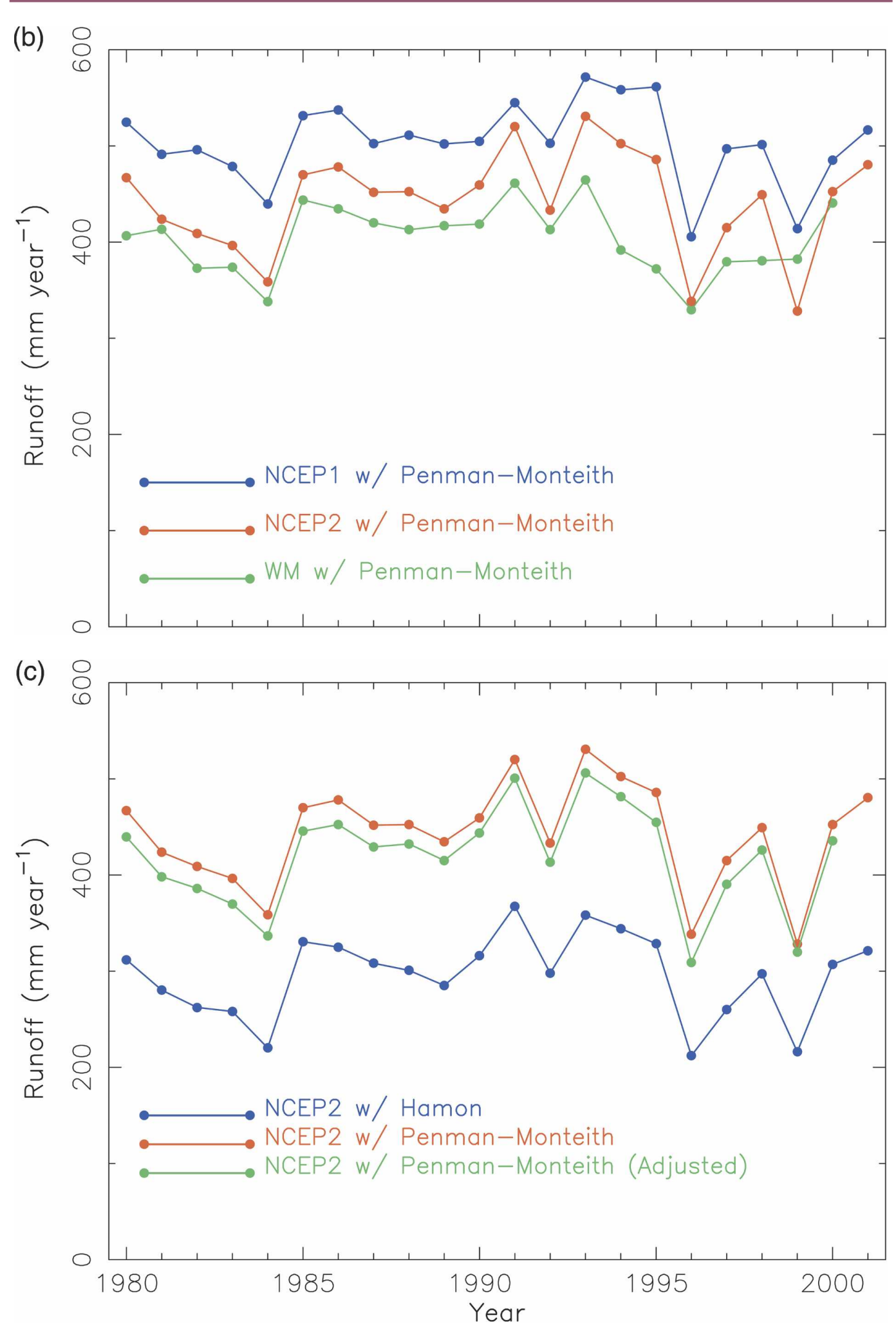

Figure 4. (Continued) 


\section{Earth Interactions • Volume 10 (2006) • Paper No. 18 • Page 13}

and Hamon PET (Figure 4a) are attributable, in part, to colder air temperatures (lower ET $\rightarrow$ higher runoff) in the NCEP2 dataset (Figure 1). Use of the NCEP1 climate data results in the highest runoff, WM climate inputs produce the lowest runoff, and all three simulations using the PM PET method show higher runoff than the model runs using Hamon. Runoff from the NCEP1 simulations is 13\%$24 \%$ higher than NCEP2 runoff depending on the PET method (Table 2), since incorporation of observed data reduces the excessive NCEP1 precipitation. Arctic precipitation in the NNR has been shown to be systematically too high (particularly in summer) due mostly to excessive convective precipitation (Serreze and Hurst 2000). When the adjusted PM method is used to account for the vapor pressure bias, simulated runoff decreases by $25-30 \mathrm{~mm} \mathrm{yr}^{-1}$ or $6 \%-7 \%$.

Runoff from simulations using the PM method show a higher snowmelt peak than those using Hamon (Figure 5). Observed runoff (i.e., discharge measured at the downstream site) lags the simulated melt peak by 1 month in all simulations. This is expected, as snowmelt-driven runoff from upstream areas often takes several weeks to reach the downstream gauge in large basins. Simulated runoff is less than observed (underestimate) for NCEP2 and WM climate with the Hamon function (Table 4). The PM method generates excess runoff for each climate

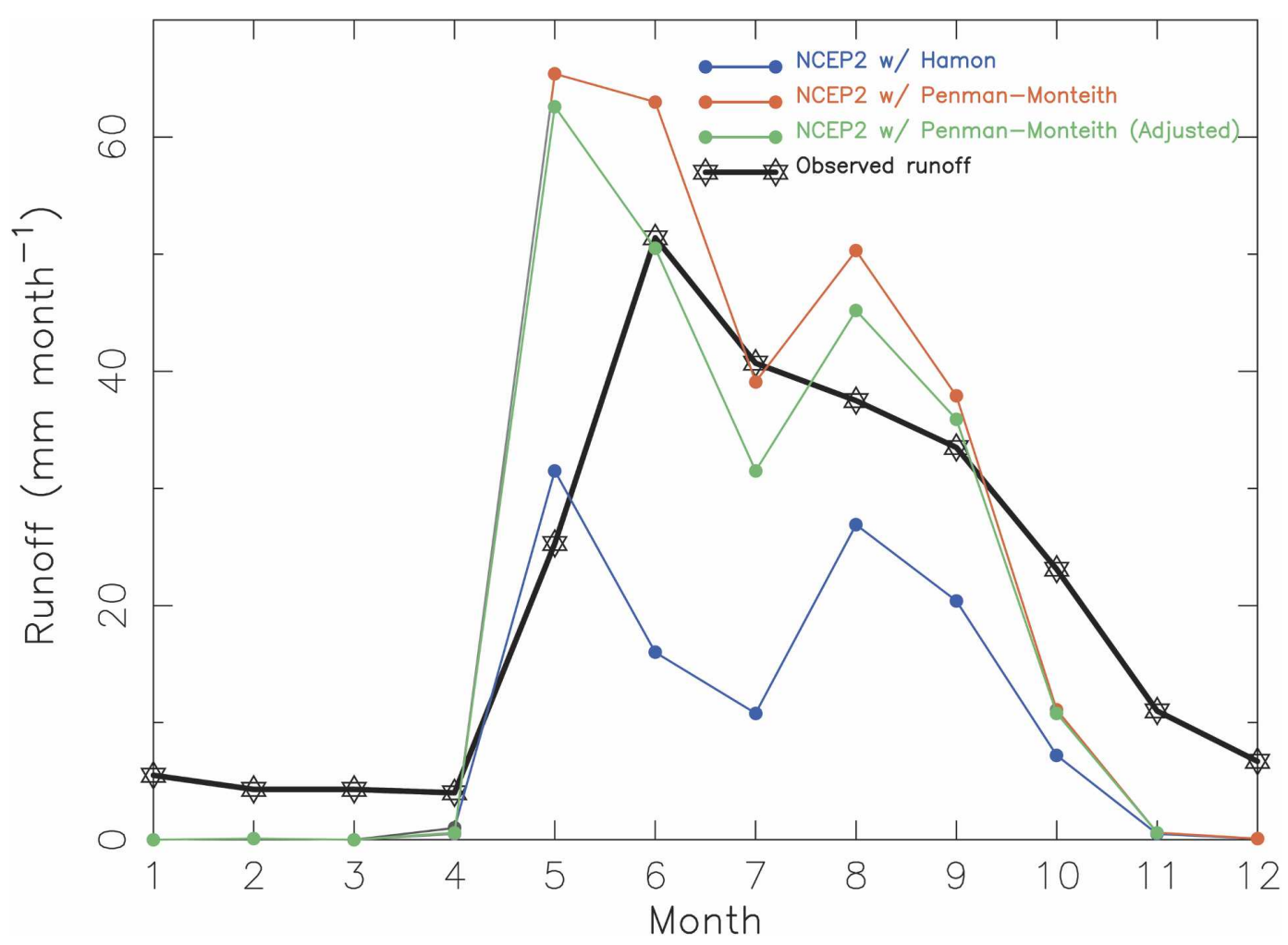

Figure 5. Long-term mean monthly runoff across the Yukon basin simulated for the period 1980-2001. Observed runoff is discharged as a unit depth across the Yukon River basin. Simulated runoff taken from model runs using the NCEP2 climate with each of the PET methods. 
Earth Interactions - Volume 10 (2006) - Paper No. 18 • Page 14

driver, a result of higher vapor pressure and low simulated ET. Adjusting the NNR vapor pressures lowers runoff (7\%-13\%). Across the Yukon River basin generally good agreement between simulated and observed runoff is noted; simulated runoff differs from the observed by $7 \%$ for the NCEP2 and WM climate drivers when the adjusted PM PET method is used (Figure 6). Runoff generated with NCEP1 climate exceeds observed values regardless of the PET method used. The average mean absolute difference (MAD) is 200, 60, and $70 \mathrm{~mm} \mathrm{yr}^{-1}$ for NCEP1, NCEP2, and WM climate, respectively.

\section{Discussion}

Model simulations of evapotranspiration across forested interior regions are more strongly affected by synoptic weather conditions (e.g., vapor pressure deficits) than tundra locations. This is expected, as transpiration is the dominant source of water loss in forested regions (soil evaporation is dominant in tundra locations), and synoptic controls such as vapor pressure deficit are an important driver in these areas (Beringer et al. 2005). Feedbacks between radiation, precipitation, and

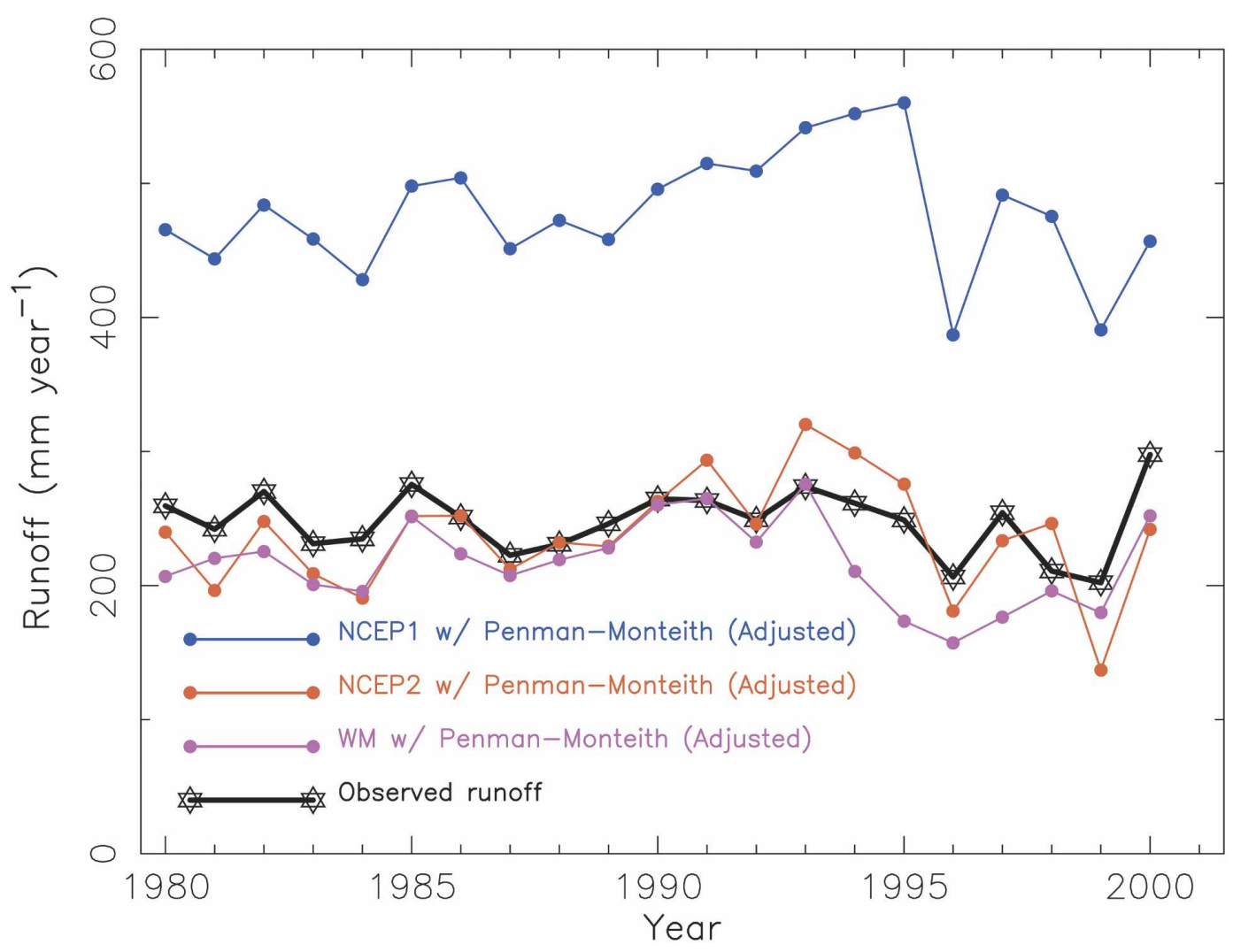

Figure 6. Observed and simulated annual runoff across the Yukon basin for 19802000. Simulated runoff is drawn from model runs using each climate driver along with the adjusted PM PET method. 
soil moisture in the NNR affect the near-surface moisture amounts (Serreze and Hurst 2000). The relatively high vapor pressures result in small vapor pressure deficits, which tend to reduce ET rates when used in land surface and hydrologic models. Modeled ET rates in simulations using the Hamon PET method more closely match observed ET values across interior regions of Alaska. Downwelling shortwave fluxes in the NNR are also reportedly too high (Serreze and Hurst 2000). As opposed to the effect of elevated vapor pressure (leads to reduced ET), the biased radiation data (used in the PM PET method) would tend to increase estimated ET rates and reduce runoff. The ET rates for the PM and Hamon simulations converge toward observed values along coastal regions where evaporation from tundra vegetation dominates the surface ET flux. When the PM PET method is used, differences between simulated and observed ET at Delta Junction (forest site) suggest that greater uncertainties in simulated budgets are likely across these forest regions. Comparisons with the observed values also show that ET estimated in model runs using the Hamon PET method represent an upper bound on simulated ET rates, with lower rates when the PM method is chosen.

Monthly climatologies of simulated ET from PM are nearly identical across the three climate drivers. Differences in ET from simulations using the PM and Hamon methods are largely due to low vapor pressure deficits that drive the surfacedependent PM PET method. Simulated ET rates across the WALE domain are strongly influenced by both the vapor pressure data and the PET method chosen, with less effect from differences in precipitation data. A thorough evaluation of model-simulated ET fluxes is hampered by the paucity of observed, high-latitude ET measurements.

Simulated annual runoff shows substantial variations between model runs, with long-term means strongly dependent on which climate driver and PET function is implemented. When the PM method is used, lower ET leads to increased soil moisture storage and higher runoff estimates. The highest mean runoff (from NCEP1 climate with PM PET) is double the lowest runoff rate (WM climate with Hamon PET). Simulations using the raw NNR climate drivers (NCEP1) result in the highest runoff independent of PET function. This is due to higher summer precipitation in the NNR data. The WM climate data, which is produced from observed station records, generates the lowest runoff, as expected, since the WM archive does not incorporate precipitation gauge corrections. Precipitation in the NCEP2 dataset was produced through downscaling of the NCEP1 data based on observed data; therefore, NCEP2-derived water fluxes represent a combination of arctic reanalysis and observed climate. Model simulations with the PM method generate runoff that exceeds the observed Yukon runoff due to low ET rates. Using the adjusted vapor pressure data lowers runoff across the WALE and Yukon domains. Across all PET methods, average MAD for NCEP1 climate is a factor of 3 greater than MAD for NCEP2 or WM because of excessive precipitation in the NCEP-NCAR reanalysis.

Although good correspondence with observed runoff is noted for NCEP2 and WM climate with the adjusted PM PET method, the accuracy of these precipitation data - the most important variable for arctic hydrological models - cannot be verified. Adjustment for biases such as gauge undercatch would likely significantly change simulated water fluxes. Other sources of climate data such as the new 40-yr European Centre for Medium-Range Weather Forecasts (ECMWF) Re-Analysis 
Earth Interactions - Volume 10 (2006) - Paper No. 18 • Page 16

(ERA-40) may prove useful in improving closure of water budgets across the WALE region.

\section{Conclusions}

Three climate drivers and three methods for estimating PET were used in simulations with a water budget model to better understand our ability to simulate arctic water balances across the western Arctic region. High surface vapor pressures in the NNR tend to limit modeled PM PET and result in PWBM-simulated ET rates that are less than half the rates found when the Hamon PET function is used. Differences in precipitation have much less influence on simulated ET rates than do the vapor pressure inputs and type of model PET method used. High simulated runoff noted in simulations driven by NCEP1 climate reflects the excessive precipitation in the NNR. More modest runoff rates are noted in simulations using NCEP2 precipitation-a combination of atmospheric reanalysis and station observations. Agreement between simulated and observed runoff to within $7 \%$ occurs with NCEP2 and WM climate drivers when the adjusted PM PET method is used. We find that simulations of arctic evapotranspiration and runoff are strongly dependent on the quality of time series data used to drive the model. These results suggest that closure of simulated water budgets across Arctic regions is strongly dependent on thorough evaluations of model requirements, potential biases in climatic datasets, and comparisons with observed data where available.

Acknowledgments. This work was supported by NSF Grants OPP-0094532, OPP0230243, and OPP-9910264 and NASA Grant NNG-04GM19G. We wish to thank Alexander Shiklomanov (UNH) for assistance with river gauge data, Monika Calef (University of Alaska Fairbanks) for providing the vegetation data, and Cort Willmott and Kenji Matsuura (University of Delaware) for their help with the Willmott-Matsuura archive. David McGuire (University of Alaska Fairbanks) is acknowledged for his comments on an earlier manuscript draft. We also thank Anthony Federer (UNH) for the fruitful discussions on process modeling.

\section{Appendix A}

\section{PET Estimation}

Hamon as given by Hamon (Hamon 1963):

$$
\mathrm{PE}_{r}=715.5 \Lambda e^{*}\left(T_{m}\right) /\left(T_{m}+273.2\right) \text {. }
$$

Penman-Monteith (PM) as given by Monteith (Monteith 1965) $\left(R_{n}=R_{n}-S\right.$ with $S=0)$ :

$$
c_{t} L_{v} \rho_{w} \mathrm{PE}_{s}=\frac{\Delta R_{n}+c_{p} \rho D_{a} / r_{a}}{\Delta+\gamma+\gamma\left(r_{c} / r_{a}\right)}
$$

\section{Appendix B}

\section{Parameters}

$c_{p} \quad$ Heat capacity of air, $1005 \mathrm{~J} \mathrm{~kg}^{-1} \mathrm{~K}^{-1}$

$c_{t} \quad$ Conversion constant, $0.01157 \mathrm{Wmd}, \mathrm{MJ}^{-1} \mathrm{~mm}^{-1}$ 
Earth Interactions - Volume 10 (2006) - Paper No. 18 • Page 17

$D_{a} \quad$ Vapor pressure deficit in air, $\mathrm{kPa}, e^{*}\left(T_{a}\right)-e_{a}$

$e^{*}(T) \quad$ Saturated vapor pressure at temperature $T, \mathrm{kPa}$

$L_{v} \quad$ Latent heat of vaporization, $2448.0 \mathrm{MJ} \mathrm{m}^{-2}$

$\mathrm{PE}_{r} \quad$ Reference-surface potential evapotranspiration, $\mathrm{mm} \mathrm{day}^{-1}$

$\mathrm{PE}_{s} \quad$ Surface-dependent potential evapotranspiration, $\mathrm{mm}$ day $^{-1}$

$r_{a} \quad$ Aerodynamic resistance, $\mathrm{s} \mathrm{m}^{-1}$

$r_{c} \quad$ Surface or canopy resistance, $\mathrm{s} \mathrm{m}^{-1}$

$R_{n} \quad$ Net radiation above the surface, $\mathrm{W} \mathrm{m}^{-2}$

$T_{m} \quad$ Mean air temperature for day, ${ }^{\circ} \mathrm{C}$

$z_{a} \quad$ Reference height, $\mathrm{m}$

$\gamma \quad$ Psychrometer constant, $0.067 \mathrm{kPa} \mathrm{K}^{-1}$

$\Delta \quad$ Rate of change of vapor pressure with temperature, $\mathrm{kPa} \mathrm{K}^{-1}$

$\Lambda \quad$ Day length, days

$\rho \quad$ Density of air, $1.234 \mathrm{~kg} \mathrm{~m}^{-3}$

$\rho_{w} \quad$ Density of water, $1.0 \mathrm{Mg} \mathrm{m}^{-3}$

\section{REFERENCES}

Beringer, J., F. S. Chapin III, C. D. Thompson, and A. D. McGuire, 2005: Surface energy exchanges along a tundra-forest transition and feedbacks to climate. Agric. For. Meteor., 131, $143-161$.

Calef, M. P., A. D. McGuire, H. E. Epstein, T. S. Rupp, and H. H. Shugart, 2005: Analysis of vegetation distribution in interior Alaska and sensitivity to climate change using a logistic regression approach. J. Biogeogr., 32, doi:10.1111/j.1365-2699.2004.01185.x.

Cihlar, J., and J. Beaubien, 1998: Land cover of Canada Version 1.1. Canada Centre for Remote Sensing and Canadian Forest Service, Natural Resources Canada, CD-ROM. [Available online at http://www.ccrs.nrcan.gc.ca/optic/map_e.php.]

Federer, C. A., C. J. Vörösmarty, and B. M. Fekete, 1996: Intercomparison of methods for calculating potential evaporation in regional and global water balance models. Water Resour. Res., 32, 2315-2321.

Fekete, B. M., C. J. Vörösmarty, J. O. Roads, and C. J. Willmott, 2004: Uncertainties in precipitation and their impacts on runoff estimates. J. Climate, 17, 294-304.

Fleming, M. D., 1997: A statewide vegetation map of Alaska using phenological classification of AVHRR data. Proceedings of the Second Circumpolar Arctic Vegetation Mapping Workshop and the CAVM-North America Workshop, D. A. Walker and A. C. Lillie, Eds., USGS, 25-26.

Hamon, W. R., 1963: Computation of direct runoff amounts from storm rainfall. Int. Assoc. Sci. Hydrol. Publ., 63, 52-62.

Karl, T. R., P. Y. Groisman, R. W. Knight, and R. R. Heim, 1993: Recent variations of snow cover and snowfall in North America and their relation to precipitation and temperature variations. J. Climate, 6, 1327-1344.

Kistler, R., and Coauthors, 2001: The NCEP-NCAR 50-year reanalysis: Monthly means CD-ROM and documentation. Bull. Amer. Meteor. Soc., 82, 247-267.

Kite, G. W., and U. Haberlandt, 1999: Atmospheric model data for macroscale hydrology. J. Hydrol., 217, 303-313.

Legates, D. R., and C. J. Willmott, 1990a: Mean seasonal and spatial variability in gauge-corrected global precipitation. Int. J. Climatol., 10, 111-133.

— Theor. Appl. Climatol., 41, 11-21.

Liu, H., J. T. Randerson, J. Lindfors, and F. S. Chapin III, 2005: Changes in the surface energy 
Earth Interactions • Volume 10 (2006) - Paper No. 18 • Page 18

budget after fire in boreal ecosystems of interior Alaska: An annual perspective. J. Geophys. Res., 110, D13101, doi:10.1029/2004JD005158.

McGuire, A. D., and Coauthors, 2005: Western Arctic Linkage Experiment (WALE): Background, objectives, results, and conclusions. Earth Interactions, submitted.

Monteith, J. L., 1965: Evaporation and environment. The State and Movement of Water in Living Organisms, Cambridge University Press, 205-233.

Rawlins, M. A., R. B. Lammers, S. Frolking, B. M. Fekete, and C. J. Vörösmarty, 2003: Simulating pan-Arctic runoff with a macro-scale terrestrial water balance model. Hydrol. Process., 17, 2521-2539.

Serreze, M. C., and C. M. Hurst, 2000: Representation of mean Arctic precipitation from NCEPNCAR and ERA reanalyses. J. Climate, 13, 182-201.

— , M. P. Clark, D. H. Bromwich, A. J. Etringer, T. Zhang, and R. Lammers, 2003: Monitoring precipitation over the Arctic terrestrial drainage system: Data requirements, shortcomings, and applications of atmospheric reanalysis. J. Hydrometeor., 4, 387-407.

Su, F., J. C. Adam, L. C. Bowling, and D. P. Lettenmaier, 2005: Streamflow simulations of the terrestrial Arctic domain. J. Geophys. Res., 110, D08112, doi:10.1029/2004JD005518.

Töyrä, J., A. Pietroniro, and B. Bonsai, 2005: Evaluation of GCM simulated climate over the Canadian prairie provinces. Can. Water Resour. J., 30, 245-262.

Vörösmarty, C. J., C. A. Federer, and A. L. Schloss, 1998: Potential evapotranspiration functions compared on US watersheds: Possible implications for global-scale water balance and terrestrial ecosystem modeling. J. Hydrol., 207, 147-169.

Vose, R. S., R. L. Schmoyer, P. M. Steurer, T. C. Peterson, R. Heim, T. R. Karl, and J. Eischeid, 1992: The global historical climatology network: Long-term monthly temperature, precipitation, sea level pressure, and station pressure data. Tech. Rep. ORNL/CDIAC-53, NDP-041, Carbon Dioxide Information Analysis Center, Oak Ridge National Laboratory, Oak Ridge, TN.

Willmott, C. J., and K. Matsuura, 2001: Arctic terrestrial air temperature and precipitation: Monthly and annual time series (1930-2000) version 1. [Available online at http:// climate.geog.udel.edu/ climate/.]

Yang, D., D. Kane, Z. Zhang, D. Legates, and B. Goodison, 2005: Bias corrections of long-term (1973-2004) daily precipitation data over the northern regions. Geophys. Res. Lett., 32, L19501, doi:10.1029/2005GL024057.

Earth Interactions is published jointly by the American Meteorological Society, the American Geophysical Union, and the Association of American Geographers. Permission to use figures, tables, and brief excerpts from this journal in scientific and educational works is hereby granted provided that the source is acknowledged. Any use of material in this journal that is determined to be "fair use" under Section 107 or that satisfies the conditions specified in Section 108 of the U.S. Copyright Law (17 USC, as revised by P.IL. 94-553) does not require the publishers' permission. For permission for any other form of copying, contact one of the copublishing societies. 